Журнал«Герстективита інновації наукц»

(Серія«Гедагогіка», Серія«ГТихологія», Серія«Медицинв»

№2(7) 2022

УДК: 159.922.1:159.923.2

https://doi.org/10.52058/2786-4952-2022-2(7)-968-979

Серга Тетяна Олексіївна кандидат соціологічних наук, доцент, доцент кафедри соціальної роботи та психології, Національний університет «Запорізька політехніка», вул. Жуковського, 64, м. Запоріжжя, 69063, тел.: (061) 764-25-06, https://orcid.org/0000-0003-0683-2070.

Білоусенко Максим Володимирович кандидат економічних наук, доцент кафедри соціальної роботи та психології, Національний Університет «Запорізька політехніка», вул. Жуковського, 64, м. Запоріжжя, 69063, тел.: (061) 764-25-06, https://orcid.org/0000-0003-3769-5144.

\title{
ПСИХОЛОГІЧНІ ФАКТОРИ ПОРУШЕННЯ ХАРЧОВОЇ ПОВЕДІНКИ У ЖІНОК СЕРЕДНЬОГО ВІКУ
}

Анотація. Стаття розкриває проблему харчування та харчової поведінки, яка $є$ дуже актуальною на теперішній час у всьому цивілізованому світі, особливо для жінок. Високий темп життя ускладнює правильне харчування, а це призводить до численних психосоматичних відхилень, таких як ожиріння, булімія й анорексія, які, у свою чергу, зумовлюють психологічну та соціальну дезадаптацію багатьох жінок.

Порушення харчової поведінки у жінок середнього віку виникають на фоні розповсюджених у сучасній суспільній свідомості стандартів «жіночої краси» та інших соціально-обумовлених та психологічних факторів. Реальність призводить до незадоволення жінкою своєю зовнішністю, яка 3 часом переростає в психологічні (та психічні) порушення.

Експериментальне дослідження дозволило виявити психологічні фактори, що впливають на порушення харчової поведінки у жінок середнього віку. Так, визначено, що більшість жінок, що досліджувалися, мають низький рівень життєвої задоволеності, середній рівень позитивної оцінки себе та своїх вчинків, узгодженості між поставленими та досягнутими цілями, також мають високий рівень занепокоєння про власне тіло та вагу. Багато хто боїться бути критикованими та стати жертвою дискримінації, порівнюють своє життя 3 «ідеальним» життям людей в соціальних мережах, намагаючись відповідати заданим вимогам. Надлишковий перфекціонізм призводить до безкінечного прагнення до досконалості і $є$ причиною болісного бажання контролювати себе, свій апетит і своє тіло, що розгортає великий простір для виникнення психологічних та психічних проблем, як внутрішньо-особистісного, так i міжособистісного характеру.

Автори доводять, що для ефективної боротьби з харчовими порушеннями необхідна активна просвіта суспільства про небезпеку цих порушень, а також 
обережне, уважне ставлення до встановлених стандартів жіночих фігур. Особливе значення, звичайно, має своєчасно надана професійна психологічна допомога.

Ключові слова: харчова поведінка, психологічні особливості харчової поведінки, порушення, розлади, жінки середнього віку, психологічні фактори.

Serha Tetyana Oleksiivna Candidate of sociological sciences, associate professor, assistant professor of department of social work and psychology, National University «Zaporiz'ka Politehnika», Zhukovskiy St., 64, Zaporizhzhya, 69063, tel.: (061) 764-25-06, https://orcid.org/ 0000-0003-0683-2070.

Bilousenko Maksym Volodimirovich Candidate of Economic sciences, assistant professor of department of social work and psychology, National University «Zaporiz'ka Politehnika», Zhukovskiy St., 64, Zaporizhzhya, 69063, tel.: (061) 764-25-06, https://orcid.org/0000-0003-3769-5144.

\section{PSYCHOLOGICAL FACTORS OF EATING DISORDERS IN MIDDLE AGE WOMEN}

Abstract. The article reveals the problem of nutrition and eating behavior, which is very relevant today in the civilized world, especially for women. The high pace of life complicates proper nutrition, and this leads to numerous psychosomatic disorders, such as obesity, bulimia and anorexia, which, in turn, lead to psychological and social maladaptation of many women.

Eating disorders among middle-aged women occur against the background of widespread in modern public consciousness standards of «female beauty» and other social and psychological factors. Reality leads to dissatisfaction with a woman's appearance, which over time grows into psychological (and mental) disorders.

The experimental study revealed psychological factors influencing eating disorders among middle-aged women. Thus, it was determined that most of the women surveyed have a low level of life satisfaction, a medium level of positive assessment of themselves and their actions, consistency between goals and goals, and have a high level of concern about their own body and weight. Many people are afraid of being criticized and discriminated against, compare their lives with the «ideal» life of people from social media, trying to meet the requirements. Excessive perfectionism leads to an endless desire for perfection and is the cause of a painful desire to control themselves, their appetite and their body, which opens up a lot of space for psychological and mental problems, both intrapersonal and interpersonal.

The authors prove that the effective fight against eating disorders requires active public education about the dangers of these disorders, as well as careful attention to the established standards of female figures. Of particular importance, of course, is the timely provision of professional psychological assistance.

Keywords: eating behavior, psychological features of eating behavior, disorders, disorders, middle-aged women, psychological factors. 
Журнал«Герспективитаінновації наукиљ

(Серія«Гедагогіка», Серія«Гцихологія», Серія«Медицинв»

№2(7) 2022

Постановка проблеми. Проблема порушення харчової поведінки в сучасній медицині та психології займає особливе місце. 3 кожним роком в світі повільно, але неухильно, зростає кількість людей з різноманітними варіантами патології харчової поведінки. За даними ВООЗ, у світі постійно підвищується кількість осіб з ожирінням, а порушення харчової поведінки спричиняють найвищий рівень смертності серед людей 3 психічними захворюваннями. Загальновизнане, що зараз, через пандемію COVID-19, емоційне переїдання процвітає як ніколи.

Харчова поведінка значною мірою впливає на якість життя, тому, що набута звичка переїдати супроводжується жорсткою самокритикою, що ускладнює позбавлення від шкідливої залежності. Проблема розробки науковообгрунтованих технологій збереження здоров'я - це важлива задача сучасної науки.

Вивчення взаємозв'язків особливостей харчової поведінки жінок з іншими їх психологічними характеристиками дозволить виявити істотні психологічні закономірності та механізми цього аспекту життя людини. У свою чергу, це дасть змогу розкрити науково обгрунтований шлях психологічної допомоги особам 3 порушеннями харчової поведінки, що буде сприяти оздоровленню населення України, як у психологічному, так і в соматичному плані.

Аналіз останніх досліджень і публікацій. Питання дослідження проблем харчової поведінки актуалізоване в психологічній та медичній науці лише наприкінці XX століття, а психологічні дослідження здебільшого зосереджені у сфері клінічної психології на iï критичних проявах - анорексії та булімії. Прояви харчової поведінки емоціогенного, екстернального та обмежувального типу $є$ предметом комплексного дослідження та розглядаються як серйозна проблема багатофакторної етіології, загрозлива для здоров'я індивіда та притаманна не лише людям з надмірною вагою, але й індивідам 3 нормальною чи зниженою вагою.

Аналіз останніх досліджень і публікацій свідчить, що цій проблемі присвячено чимало зарубіжної та вітчизняної літератури. Так, тему порушень харчової поведінки у своїх працях неодноразово піднімали такі відомі вчені, як Р.Л. Палмер, К.С. Кендлер, В.В. Крилов, М.О. Цивілько, Г.К. Ушаков, Н.Д. Жигалова, І.В. Кульчинська та інші.

Увага багатьох науковців зосереджувалася на різних аспектах харчової поведінки (Т.І. Алексєєва, Л.Ф. Артюх, О.Ю. Барташук, О.В. Бацилєва, П. Бурд’є, Л.Ф. Бурлачук, М.О. Бутінов, Ж.П. Вірна, С.О. Кириленко, В.А. Косяк, Н.І. Кошель, Л.В. Сохань, С. Тірадо, Н. Шнаккенберг, А.І. Яблонський та ін.), зокрема, на психологічних особливостях розладів даної сфери (О.І. Богучарова, Д.Т. Вербіц, Р. Міланезе, Л.А. Найдьонова, Ж. Нардоне, B.I. Шебанова та ін.).

Фундаментальними засадами дослідження психологічних особливостей харчової поведінки жінок $\epsilon$ положення таких теоретичних напрямів $\mathrm{y}$ психологічній науці, як: теорія діяльності (Б.Г. Ананьєв, Г.С. Костюк, 
О.М. Леонтьєв, С.Л. Рубінштейн, Б.М. Теплов та ін.); генетична психологія (Л.С. Виготський, В.В. Давидов, Д.Б. Ельконін, Г.С. Костюк, О.Р. Лурія, С.Д. Максименко, М.В. Папуча); концепції розвитку особистості й суб' єктного підходу (К.О. Абульханова-Славська, І.Д. Бех, Л.І. Божович, М.Й. Боришевський, А.В. Брушлінський, Л.Ф. Бурлачук, О.М. Леонтьєв, С.Д. Максименко, В.А. Петровський, С.Л. Рубінштейн, В.І. Слободчиков, В.О. Татенко).

Теоретико-методологічними проблемами безпосередньо психології харчової поведінки людини займалися Г.Ш. Ашурова, О.В. Бацилєва, Л.Ф. Бурлачук, М.В. Гриньова, Л.В. Дудар, Г.Д. Золотова, І.Г. Малкіна-Пих, Т. Манн, В.Д. Менделевич, Р. Міланезе, О.К. Напрєєнко, Дж. Нардоне, Я.І. Олексієнко, Д. Перлмуттер, А.В. Пріленська, А.М. Скрипніков, О.О. Скугаревський, В.І. Шебанова, Н. Шнаккенберг та інші.

Виходячи $з$ великої актуальності проблеми та, не дивлячись на значний доробок науковців, дієвих підходів до боротьби 3 порушеннями харчової поведінки ще дуже мало.

Мета статті. На основі теоретичного та емпіричного дослідження окреслити психологічні фактори, що впливають на порушення харчової поведінки жінок середнього віку.

Виклад основного матеріалу. Історично склалося так, що порушеннями харчової поведінки більшою мірою страждають представниці жіночої статі. Це можна пов'язати 3 тим, що в процесі розвитку суспільства і культури $з$ кожним новим десятиліттям до зовнішнього вигляду жінок пред'являлися все більш суворі вимоги. У різні часові періоди в еталони зводилися жіночі фігури певних типів і обсягів, а з розвитком суспільства відбувалося поступове зменшення обсягів «жіночого ідеалу».

3 появою ЗМІ суспільству почали транслювати «ідеальні» фігури моделей, вага яких в середньому була на 8-10\% нижче ваги середньостатистичної жінки. Сьогодні це значення перевищує 20\%. Також, середньостатистична актриса, модель або танцівниця сьогодні худіше на 95\% відсотків інших жінок. Величезна кількість реклами засобів для схуднення, дієт, «правильних» продуктів для харчування також провокують розвиток харчових порушень [1].

Варто відзначити, що частіше за все порушення харчової поведінки 3'являються у дівчаток у віці 12-14 років, коли дитяча психіка схильна до впливу ззовні і вбирає в себе всю інформацію, що надходить, не аналізуючи іiі правильність і цінність. Так, маленькі дівчатка починають рівнятися на відомих медійних особистостей, які активно пропагують «правильне» харчування або різного роду дієти [2].

Варто відзначити, що крім впливу ЗМI, на розвиток порушення харчової поведінки впливає і соціум, в якому знаходиться людина. Іноді тригером для появи захворювання може виступати одне жартівливе або кілке зауваження 3 приводу фігури, ваги, зовнішнього вигляду дівчини. Надалі жінка стає одержимою питаннями своєї ваги і зовнішнього вигляду, зациклюється на 
харчуванні та піддається ще більшому розвитку захворювання, намагаючись стати «ідеальною». Соціальні мережі мають вагомий вплив на розвиток харчових порушень. Групи та публічні сторінки в Фейсбуці, присвячені дієтам, ідеалізують зайву худорлявість, сторінки в Instagram показують «красиве» життя худих моделей.

Найбільшого апогею проблема схуднення досягає у «дорослому віці» жінки, коли вже не так легко приділити увагу своєму образу харчування, руховій активності, я к у підлітковому чи молодому віці. Доросла жінка зайнята переважно сімейними обов'язками та професійною діяльністю. А проблема ідеальної фігури ще більше втягує жінку, з огляду на поступову втрату молодості.

Цей віковий етап дуже важливий в житті людини. Ерік Еріксон вважав, що середній вік, як і інші періоди життя, ставить перед людьми певні завдання розвитку та вимагає від них оволодіння певними вміннями і навичками, щоб отримати позитивний досвід і знайти душевний спокій на наступній стадії життя. Згідно Еріксону, головне завдання розвитку у середньому віці полягає у виборі між стагнацією та тим, що сам Еріксон називав генеративністю, тобто поширенням інтересів за межі інтересів до себе самого - на більш широкі області ідентифікації з іншими людьми, зі всією сукупністю людей в цілому та 3 майбутніми поколіннями [3].

Отже, до основних порушень харчової поведінки відносять:

- компульсивне (нападоподібне) переїдання;

- емоціональне (психогенне) переїдання;

- орторексію;

- діабулімію;

- дранкорексію;

- нервову анорексію;

- нервову булімію;

- розлад неконтрольованого переїдання;

- пікацизм та румінацію;

- вибірковий розлад харчування та інші [4].

Деякі 3 цих станів відносять до порушень, а деякі до розладів харчової поведінки. Останні вважаються психічними захворюваннями, для яких характерна стурбованість, що пов'язана 3 їжею та харчуванням. Часто порушення мають ускладнення у вигляді втрати ваги, та якщо до цього приєднується заклопотаність тим, щоб мати худе тіло, то вони можуть переходити у вторинні стани, ускладнюватися та отримувати форму психічних розладів. Найбільш часто це явище спостерігається в прозахідних культурах.

Досліджуючи порушення харчової поведінки та їх наслідки, можна зазначити, що на фоні загального дисбалансу та напруги, у людини формуються внутрішньоособистісні та міжособистісні проблеми, такі як: непорозуміння 3 близькими, конфлікти зі сім'єю та друзями; нереалізація уявлених мрій та планів; поява страхів, низької самооцінки, тривоги, постійний стрес, розлади психічного генезу. 
На основі аналізу спеціалізованої літератури, можна окреслити основні соціально-психологічні фактори, що впливають на виникнення, підтримку та розвиток порушень харчової поведінки у жінок середнього віку.

Отже, передусім такими факторами є сприйняття, переконання, установки та цінності. Жінки вибудовують власні сприйняття, переконання та установки щодо їжі на основі культурних цінностей та психосоціальних факторів, які формують їх харчові вибори. Такі ширші культурні конструкції можуть не завжди співпадати зі строгими науковими поглядами на безпечність чи харчову поживність тих або інших продуктів.

Жінка здебільшого споживає їжу у присутності інших. Дослідження показують, що ефект соціальної фасилітації призводить до нижчого рівня споживання їжі наодинці та, відповідно, до вищого в обстановці групового споживання, особливо, коли такі групи складаються зі знайомих між собою людей. Родина та друзі становлять головне джерело зразків для наслідування, $\mathrm{i}$ так само є основними факторами групового тиску у справі споживання тих чи інших харчів (включаючи продукти 3 підвищеним чи зниженим вмістом жирів) або куштування нових продуктів. Родинна залученість $є$ важливою для формування та подальшої підтримки харчових поведінкових змін, як це показано у дослідженнях щодо зниження ризиків серцево-судинних захворювань та щодо лікування надмірної ваги і пов'язаних із нею харчових розладів. Очевидно, що брак соціальної підтримки здатний зруйнувати індивідуальні спроби харчових змін повністю чи принаймні критично зменшити успішність таких спроб [5].

Наступним психологічним фактором є ЗМI та реклама. Засоби масової інформації є одним із ключових джерел інформації про їу та харчування для багатьох людей. Більшість рекламних бюджетів витрачають компанії, які виробляють упаковані солодкі та жировмісні продукти 3 високим рівнем обробки. Рекламні повідомлення, які апелюють до «здорових» продуктів, зазвичай збільшують обсяги продажу [5].

Доступність та різноманіття харчових продуктів, також є фактором, що стимулює порушення. Доступність харчових продуктів у публічній сфері (у ресторанах, кафе, школах, лікарнях, магазинах, їдальнях та на робочих місцях) залежить від низки взаємопов'язаних факторів, таких, як різноманіття. Жінки, які споживають більше різноманіття харчів, зазвичай їдять більше. Однак, різноманіття також може бути пов'язане із підвищеним споживанням жирів, цукру, солі чи холестерину [6].

3 цього випливає наступний фактор - харчові вподобання. Більшість жінок зазначають, що їх харчові вибори значною мірою визначаються смаком на противагу будь-яким міркуванням щодо поживності чи корисності. Поняття «смаку» у цьому випадку включає також запах та оральне сприйняття текстури страви. Сенсорні реакції-відповіді на смак, запах, зовнішній вигляд та текстуру харчових продуктів є головним чинником впливу на харчові вподобання та звички. Застереження щодо здоров’я, маси тіла та зовнішнього вигляду можуть 
призводити до харчових обмежень, уникання жирів та цукру, та збільшення частки «здорових», однак непривабливих у інших аспектах харчових продуктів. Цей конфлікт між когнітивним та сенсорним факторами у жінок $є$ темою багатьох досліджень з старіння, надмірної ваги та харчових розладів [6.].

Наступним фактором порушення харчової поведінки є «знання». Жінки можуть використовувати власні знання для формування когнітивних зв'язків між харчуванням та здоров'ям, змінюючи таким чином власну поведінку, але самі по собі знання не є завжди ефективним. В сучасному світі інформація щодо здорового способу життя та харчових ризиків є вільно доступною найширшим прошаркам населення, однак, багато жінок або не знають, як застосовувати цю інформацію у повсякденному житті, або недостатньо мотивовані до реальних змін власної харчової поведінки. Таким чином, у аспекті інформаційного впливу на поширення «здорових» моделей харчування слід визнати, що поінформованість далеко не завжди $є$ запорукою значного впливу на реальну харчову поведінку жінки [6].

Як бачимо, серед факторів порушення харчової поведінки сучасної жінки середнього віку чільне місце займають соціальні впливи - оточення, засоби масової інформації та реклама, доступність та різноманіття продуктів. Численні дослідження вказують також на важливу роль соціального научання та знань про те, яка їжа є здоровою, правильною, корисною.

3 метою виявлення психологічних факторів порушення харчової поведінки у жінок середнього віку в емпіричній площині, було проведено й власне дослідження.

Існує багато вікових класифікацій, розроблених фахівцями з різних галузей людського знання. Проаналізувавши різні погляди на вікову періодизацію (Д.Б. Бромлей, Е. Еріксона, В.В Бунак та ін.), для свого дослідження ми обрали наступні межі середнього віку - 25-45 років.

Всього в досліджені взяли участь 76 жінок у вказаних вікових межах, які суб'єктивно усвідомлюють, що мають порушення в харчуванні на психологічному рівні. Матеріал для аналізу психологічних факторів порушення харчової поведінки у жінок середнього віку зібраний за допомогою наступних стандартизованих методик:

- опитувальник «Індекс життєвої задоволеності» (адаптація Н.В. Паніної) [7]; - методика «Шкала оцінки харчової поведінки» (російськомовна адаптація - О.А. Ільчик, С.В. Сивуха, О.А. Скугаревський, С. Суїхи [8];

- методика «Визначення впевненості в собі» (автор Спенсер Рейзас).

Опитувальник закритого типу «Індекс життєвої задоволеності» був використаний для діагностики загального індексу життєвої задоволеності, зацікавленості у житті, оцінки власних дій і досвіду, загального фону настрою та ставлення до себе, складається з 20 тверджень, які далі розділяються на 5 шкал.

Методика «Шкала оцінки харчової поведінки» оцінює фактори, які можуть вказувати на розвиток порушень харчової поведінки, а саме: часте занепокоєння щодо ваги, наявність епізодів голодування або переїдання, систематичні спроби 
схуднути, впевненість в своїй здатності розпізнавання голоду та ситості, рівень перфекціонізму, завищені очікування та заборона допускати помилки, рівень самотності, відчуття небезпеки оточуючого середовища, недовіра. Ця методика містить 51 твердження, які розділені на 7 субшкал.

Методика «Визначення впевненості в собі» оцінює рівень впевненості в собі, для жінок з 25 років, не передбачає ніяких обмежень щодо професійних, освітніх і соціальних особливостей, складається з 30 тверджень, які описують різні варіанти поведінкових ситуацій.

Обсяги статті не дають можливості представити усі отримані результати дослідження та їх аналіз, тому наведемо тут тільки основні показники (див. табл. 1, 2, 3).

Узагальнені результати діагностики за шкалами опитувальника

Таблиия 1

«Індекс життєвої задоволеності»

(від кількості опитаних / \%)

\begin{tabular}{|l|l|r|r|r|r|}
\hline $\begin{array}{l}\text { № } \\
\text { 3/п }\end{array}$ & \multicolumn{1}{|c|}{ Шкала } & $\begin{array}{r}\text { Високи } \\
\text { й рівень }\end{array}$ & $\begin{array}{r}\text { Середн } \\
\text { ій рівень }\end{array}$ & $\begin{array}{r}\text { Низьки } \\
\text { й рівень }\end{array}$ & $\begin{array}{c}\text { Усь } \\
\text { ого }\end{array}$ \\
\hline 1. & $\begin{array}{l}\text { Зацікавленість життям } \\
\text { та послідовність в } \\
\text { досягненні цілі }\end{array}$ & $6 / 8 \%$ & $44 / 58 \%$ & $26 / 34 \%$ & $76 / 100 \%$ \\
\hline 2. & $\begin{array}{l}\text { Узгодженість між } \\
\text { поставленими і } \\
\text { досягнутими цілями }\end{array}$ & $14 / 18 \%$ & $38 / 50 \%$ & $24 / 32 \%$ & $76 / 100 \%$ \\
\hline 3. & $\begin{array}{l}\text { Позитивна оцінка себе } \\
\text { та своїх вчинків }\end{array}$ & $14 / 18 \%$ & $38 / 50 \%$ & $24 / 32 \%$ & $76 / 100 \%$ \\
\hline 4. & $\begin{array}{l}\text { Загальний настрій жінок } \\
\text { середнього віку }\end{array}$ & $16 / 21 \%$ & $40 / 50 \%$ & $20 / 26 \%$ & $76 / 100 \%$ \\
\hline
\end{tabular}

Таблиия 2

\section{Узагальнені результати діагностики за шкалами методики «Шкала оцінки харчової поведінки»}

(від кількості опитаних / \%)

\begin{tabular}{|l|l|c|c|c|c|}
\hline $\begin{array}{c}\text { № } \\
\text { 3/п }\end{array}$ & \multicolumn{1}{|c|}{ Шкала } & $\begin{array}{c}\text { Високий } \\
\text { рівень }\end{array}$ & $\begin{array}{c}\text { Середній } \\
\text { рівень }\end{array}$ & $\begin{array}{c}\text { Низький } \\
\text { рівень }\end{array}$ & Усього \\
\hline 1. & $\begin{array}{l}\text { Шкала «Прагнення до } \\
\text { стрункої статури» }\end{array}$ & $35 / 26 \%$ & $20 / 28 \%$ & $21 / 46 \%$ & $76 / 100 \%$ \\
\hline 2. & $\begin{array}{l}\text { Шкала «Незадоволеність } \\
\text { образом тіла» }\end{array}$ & $40 / 53 \%$ & $24 / 31 \%$ & $12 / 16 \%$ & $76 / 100 \%$ \\
\hline 3. & $\begin{array}{l}\text { Шкала «Неефективність. } \\
\text { Відчуття власної } \\
\text { неадекватності» }\end{array}$ & $20 / 26 \%$ & $18 / 24 \%$ & $38 / 50 \%$ & $76 / 100 \%$ \\
\hline 4. & Шкала «Перфекціонізм» & $42 / 55 \%$ & $18 / 24 \%$ & $16 / 21 \%$ & $76 / 100 \%$ \\
\hline 5. & $\begin{array}{l}\text { Шкала «Недовіра в } \\
\text { соціальних стосунках» }\end{array}$ & $2 / 3 \%$ & $46 / 60 \%$ & $28 / 37 \%$ & $76 / 100 \%$ \\
\hline 6. & $\begin{array}{l}\text { Шкала «Інтероцептивна } \\
\text { некомпетентність» }\end{array}$ & $18 / 24 \%$ & $14 / 18 \%$ & $44 / 58 \%$ & $76 / 100 \%$ \\
\hline
\end{tabular}


Журнал«Герспективитаінновації наукиљ

(Серія «Гедагогіка», Серія «Гиихологія», Серія «Медицин»»

№2(7) 2022

Таблиия 3

Узагальнені результати діагностики за методикою «Визначення впевненості в собі»

\begin{tabular}{|c|c|c|}
\hline Рівень впевненості в собі & Кількісний розподіл & $\begin{array}{c}\text { У відсотках від кількості } \\
\text { опитаних }\end{array}$ \\
\hline Високий & 14 & $18 \%$ \\
\hline Середній & 34 & $45 \%$ \\
\hline Низький & 28 & $37 \%$ \\
\hline Усього & 76 & $100 \%$ \\
\hline
\end{tabular}

Отже, за результатами проведеного емпіричного дослідження встановлено, що у більшості жінок 3 обстеженої групи низький рівень життєвої задоволеності, пасивне ставлення до життєвих негараздів та прийняття за належне всього, що відбувається з особою. При середньому рівні задоволеності, жінкам властива впевненість та узгодженість між поставленими і досягнутими цілями; правильність проживання свого життя ставиться під сумнів, присутня емоційна та психологічна напруга, яка викривляе здатність помічати позитивні аспекти власного життя.

Виявлена пряма залежність між досліджуваними ознаками незадоволеністю образом тіла й індексом життєвої задоволеності. Задоволеність своїм життям складається 3 індивідуально-суб'єктивної оцінки особистістю своїх досягнень, потреб, бажань, цілей і того, що відбувається навколо. Задоволення життям спонукає до відчуття задоволеності собою та своїм тілом, зокрема. Високий рівень незадоволеності образом тіла (40 осіб з 76) і низький рівень життєвої задоволеності (38 осіб з 76) показує, що постійна внутрішня критика, смуток та печаль можуть бути причиною виникнення порушень харчової поведінки та низької самооцінки.

Переважаючим типом уявлень про власне тіло у жінок, що досліджувалися, $€$ високий рівень занепокоєння про власне тіло, вагу і наявність у їх житті періодів дієт і важких фізичних навантажень для схуднення. Жінки середнього віку бояться бути критикованими та стати жертвою дискримінації, порівнюють своє життя 3 «ідеальним» життям людей в соціальних мережах, намагаючись відповідати заданим вимогам. Дані свідчать про розвинуте відчуття контролю досліджуваних над власним життям та загальною безпекою. У частини досліджуваної групи зафіксовано погіршення психічного стану, виникнення тривоги, гніву, безсоння, страху, дратівливості, і втрата віри у «світле майбутнє» через безпорадність та власну неефективність у контролі свого життя.

Також жінкам, що прийняли участь у дослідженні, властивий високий рівень перфекціонізму. Жінки, внаслідок цього, сприймають себе занадто критично, вкрай зосередженні на своїх особистих недоліках, постійно розмірковуючи про те, як вдосконалити свою зовнішність, уникнути можливої критики та відповідати «встановленим» вимогам. Прагнення до досконалості $€$ можливою причиною прагнення контролювати себе, свій апетит і своє тіло, що розгортає великий простір для виникнення порушень харчової поведінки.

976 
Щодо показника впевненості в собі, то у досліджених жінок переважає середній показник (34 жінки), далі йде низький показник (28 жінок). Невпевненість проявляється у сумнівах у своїх уміннях, навичках, силах при виконанні замисленого, на грунті чого виникає побоювання, страх, а в критичних випадках навіть відмова від виконання активних дій. Високий рівень впевненості мають 14 жінок, де 2 з них можуть бути описані як самовпевнені.

Отримані результати можна пояснити тим, що середній вік, часто асоціюється $з$ такими процесами, як самоаналіз та рефлексія. Самооцінка проходить шлях порівняння ідеального «Я» з реальним. Але ідеальне «Я» ще не являється надійним і вивіреним, може бути випадковим, а реальне «Я» ще всебічно не оцінено самою особистістю. Це об'єктивне протиріччя в розвитку особистості жінки середнього віку може викликати у неї внутрішню невпевненість в собі, яка іноді супроводжується зовнішньою агресивністю, залежністю від чужої думки або відчуттям неясності, малозрозумілості.

Особистість, аналізуючи власні досягнення у багатьох видах діяльності, приймаючи до уваги думки інших людей про себе, самостійного аналізу своїх якостей, вмінь і здібностей, формує почуття самоповаги. Самоповага має багато вимірів, включає до себе задоволеність собою, всебічне прийняття себе, почуття власної гідності, узгодженість ідеального та реального «Я». Тобто, самооцінка жінки середнього віку безпосередньо пов'язана 3 думкою оточуючих. Якщо вона не відповідає критеріям ідеальності, загальноприйнятим стандартам, поширеним в суспільній думці, жінка починає жорсткіше ставитись до себе, намагатися підтягнутися до вимог і стандартів, що зумовлює хронічну незадоволеність собою та низьку оцінку власних якостей.

Вказані психологічні особливості жінок, які мають харчові порушення та виступили об'єктами дослідження, можна розглядати як особистісні фактори, що впливають на появу та розвиток цих порушень, а також часто виступають й їх наслідками, багаторазово посилюючись під впливом збільшення масштабів проблеми. Так жінка потрапляє у «замкнуте коло», 3 якого дуже важко вибратися без професійної допомоги.

Висновки. Аналізуючи порушення харчової поведінки та їх наслідки у жінок середнього віку, можна сказати, що на фоні загального дисбалансу та напруги у них формуються міжособистісні та внутрішньоособистісні проблеми, а саме: непорозуміння з близькими, конфлікти з сім'єю та друзями; нереалізація уявлених мрій та планів; поява страхів, низької самооцінки, тривоги, постійний стрес та інші розлади психологічного генезу. Несвоєчасне надання психологічної допомоги таким жінкам, що включає в себе діагностику та психокорекцію, може призвести до більш серйозних розладів харчової поведінки та загального психічного стану, вже клінічного характеру.

При аналізі факторів, які впливають на харчову поведінку жінки середнього віку, встановлено, що чільне місце серед них займають соціальні впливи - негативно позначаються засоби масової інформації та реклама, часто стимулюючи нездорові харчові вибори, доступність та різноманіття продуктів 
харчування тощо. Однак, i психологічні фактори, такі, як сприйняття, переконання, установки та цінності, які формуються на основі культурних конструкцій, можуть не завжди співпадати зі строгими науковими поглядами на безпечність чи харчову поживність тих або інших продуктів.

Емпіричне дослідження дозволило окреслити психологічні особливості жінок $з$ порушеннями харчової поведінки: занадто критичне відношення до себе, зосередження на своїх особистих недоліках, постійні міркування про те, як вдосконалити свою зовнішність, уникнути можливої критики та відповідати «встановленим» вимогам. Прагнення до досконалості виступає причиною прагнення контролювати себе, свій апетит і своє тіло, що розгортає великий простір для виникнення та розвитку різноманітних психологічних, а згодом $\mathrm{i}$ психічних порушень.

Для ефективної боротьби з харчовими порушеннями необхідна активна просвіта суспільства про небезпеку цих порушень, а також обережне уважне ставлення до встановлених стандартів жіночих фігур. Особливе значення має своєчасно надана професійна психологічна допомога.

Перспективи подальших досліджень пов'язані 3 продовженням та розширенням емпіричних досліджень психологічних факторів, які впливають на харчову поведінку людей взагалі, та жінок середнього віку, зокрема. На основі багатьох досліджень, психогенний фактор представляється обов'язковим для вивчення та корекції переважної кількості випадків порушення харчової поведінки, в сукупності з дослідженням соціального, культурно-історичного та генетичного факторів.

\section{Лimepamypa:}

1. Николаева Н.О. История и современное состояние исследований нарушений пищевого поведения (культурные и психологические аспекты). Клиническая и спещиальная психология. 2012. Том 1, № 1. URL: https://psyjournals.ru/psyclin/2012/n1/49969.shtml.

2. Бобров А. Е. Психопатологические аспекты нервной анорексии. Альманах клинической медицины. 2015. № 1 (1). С. 13-23.

3. Эрик Г. Эриксон. Детство и общество. Изд. 2-е, перераб. и доп. / пер. с англ. СПб.: Ленато, АСТ, Фонд «Университетская книга», 1996. 592 с.

4. Вознесенская Т.Г., Вахмистров А.В. Клинико-психологический анализ нарушений пищевого поведения при ожирении. Журнал неврологии и психиатрии. 2001. № 12. С. 19-24.

5. Ільницька Т. Розлади харчової поведінки: міфи та факти. HeŭpoNews. 2018. № 4-5 (97). URL: https://neuronews.com.ua/ua/archive/2018/4-5\%2897\%29/pages-6-7/rozladiharchovoyi-povedinki-mifi-ta-fakti\#gsc.tab $=0$

6. Лапина Ю. Тело, еда, секс и тревога. Что беспокоит современную женщину. Исследование клинического психолога. М. : Альпина нон-фикшн, 2018. 229 с.

7. Neugarten, B.J., Havighurst, R.J., \& Tobin, S.S. (1961). The Measurement of Life Satisfaction. Journal of Gerontology, №16, p.134-143.

8. Ильчик О.А., Сивуха С.В., Скугаревский О.А., Суихи С. Русскоязычная адаптация методики «Шкала оценки пищевого поведения». Психиатрия, психотерапия и клиническая психология. Минск. 2011. №1. С. 39-50.

\section{References:}

1. Nikolaeva, N.O. (2012). Istoriya i sovremennoe sostoyanie issledovaniy narusheniy pischevogo povedeniya (kulturnyie i psihologicheskie aspektyi). [History and current state of 
research on eating disorders (cultural and psychological aspects)]. Klinicheskaya $i$ spetsialnaya psihologiya - Clinical and special psychology T. 1, 1. Retrieved from https://psyjournals.ru/psyclin/2012/n1/49969.shtml [in Russian].

2. Bobrov, A. E. (2015). Psihopatologicheskie aspektyi nervnoy anoreksii. [Psychopathological aspects of anorexia nervosa]. Almanah klinicheskoy meditsinyi - Almanac of Clinical Medicine, 1 (1). (pp. 13-23) [in Russian].

3. Erikson, Erik G. (1996). Detstvo i obschestvo. [Childhood and society]. SPb.: Lenato, ACT, Fond «Universitetskaya kniga» [in Russian].

4. Voznesenskaya, T.G., Vahmistrov, A.V. (2001). Kliniko-psihologicheskiy analiz narusheniy pischevogo povedeniya pri ozhirenii. [Clinical and psychological analysis of eating disorders in obesity]. Zhurnal nevrologii i psihiatrii - Journal of Neurology and Psychiatry, 12. (pp. 19-24) [in Russian].

5. Il'nyts'ka, T. (2018). Rozlady kharchovoi povedinky: mify ta fakty. [Breaking up the eating habits: myths and facts]. NejroNews - NeuroNews. 4-5 (97). Retrieved from https://neuronews.com.ua/ua/archive/2018/4-5\%2897\%29/pages-6-7/rozladi-harchovoyi-povedinkimifi-ta-fakti\#gsc.tab=0 [in Ukrainian].

6. Lapina, Yu. (2018). Telo, eda, seks i trevoga. Chto bespokoit sovremennuyu zhenschinu. Issledovanie klinicheskogo psihologa. [Body, food, sex and anxiety. What worries the modern woman. Clinical psychologist research.]. M. : Alpina non-fikshn [in Russian].

7. Neugarten, B.J., Havighurst, R.J., \& Tobin, S.S. (1961). The Measurement of Life Satisfaction. Journal of Gerontology, 16, (pp.134-143) [in English].

8. Ilchik, O.A., Sivuha, S.V., Skugarevskiy, O.A., Suihi, S. (2011). Russkoyazyichnaya adaptatsiya metodiki «Shkala otsenki pischevogo povedeniya». [Russian-language adaptation of the «Eating Behavior Assessment Scale» methodology]. Psihiatriya, psihoterapiya i klinicheskaya psihologiya - Psychiatry, psychotherapy and clinical psychology. Minsk. 1. (pp. 39-50) [in Russian]. 